\title{
PATH ANALYSIS ORGANIZATIONAL COMMITMENT AND MICRO CULTURE AGAINST LEADERSHIP LECTURER IN HIGHER EDUCATION
}

\author{
Tulus Suryanto \\ Universitas Islam Negeri Raden Intan Lampung \\ Jl. Letnan Kolonel H. Endro Suratmin, Sukarame, Lampung, 35131 \\ E-mail:tulus@radenintan.ac.id
}

Abdul Rahmat

Gorontalo State University

Jl. Jendral Sudirman, Gorontalo, 96211

E-mail:abdulrahmat@ung.ac.id

\begin{tabular}{c|c|c}
\hline Received: & Revised: & Approved: \\
$04 / 06 / 2018$ & $09 / 07 / 2018$ & $15 / 06 / 2018$ \\
\hline
\end{tabular}

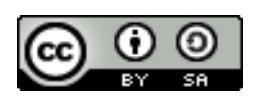

Path Analysis Organizational Commitment and Micro Culture Against

Leadership Lecturer In Higher Educationis licensed under a Creative

Commons Attribution-ShareAlike 4.0 International License

\begin{abstract}
This study aims to examine organizational commitment and micro culture towards lecturer leadership. Population in this research is all lecturer at State University of Gorontalo, obtained by sampel counted 62 people by using random sampling technique. Data collection techniques used are, tests, questionnaires and documents. Data analysis technique used is inferential analysis. Test of normality of regression data, test of regression coefficient significance, linearity test of regression equation, and hypothesis test using path analysis. The results showed that: (1) there is a direct influence of organizational commitment from the calculation of coefficient value of path
\end{abstract}


$X_{1}$ to $Y$ obtained value $0.615=\beta_{y 1}$. Based on the results of the calculation of the significance of the path coefficient obtained $t_{\text {count }}=8.023$ and $t_{\text {table }}=2.001$ at the level of significance $a=0.05$ with degrees of freedom $(d b)=59$. Because the value of $t_{\text {count }}=8.023>t_{\text {table }}=2,001$ it is concluded that the coefficient of path $\mathrm{X}_{1}$ to $\mathrm{Y}$ is significant; (2) there is direct influence of campus micro culture from calculation of coefficient value of path $X_{2}$ to $Y$ obtained value $\beta_{y 2}$ $0,363=$. Based on the results of the calculation of the significance of the path coefficient obtained $t_{\text {count }}=4.759$ and $t_{\text {table }}=2.001$ at the level of significance $a$ $=0.05$ with degrees of freedom $(\mathrm{db})=59$. Because the value of $t_{\text {count }}=4.759 \mathrm{>}$ $t_{\text {table }}=2,001$ it is concluded that the coefficient of path $X_{2}$ to $Y$ is significant; (3) there is direct influence of organizational commitment to micro culture from result of calculation of coefficient value of path $X_{1}$ to $X_{2}$ obtained value $0,753=\beta_{21}$. Based on the calculation of significance test the path coefficient obtained $t_{\text {count }}=8.852$ and $t_{\text {table }}=2,000$ at the level of significance $a=0.05$ with degrees of freedom $(\mathrm{db})=60$. Because the value of $t_{\text {count }}=8.852>t_{\text {table }}$ $=2,000$ it is concluded that the coefficient of path $X_{1}$ to $X_{2}$ is significant. Thus, the lecturer $>$ s leadership can be improved through organizational commitment and campus micro culture so that lecturers continue to improve their performance.

Keywords: Organizational Commitment, Micro Culture, and Leadership

\section{Abstrak}

Studi ini ditujukan untuk mengkaji komitmen organisasi dan budaya mikro terhadap kepemimpinan dosen. Populasi dari penelitian ini adalah semua dosen Universitas Negeri Gorontalo dengan sampel sebanyak 62 yang ditentukan secara acak. Data penelitian dikumpulkan melalui tes, kuesioner, dan dokumen. Data dianalisis secara inferensial menyakup tes normalitas regresi, tes signifkansi koefisien regresi, tes linearitas dan ekuasi regresi, dan analisis jalur untuk pengujian hipotesis. Hasil penelitian menunjukkan: (1) terdapat hubungan langsung antara komitmen organisasi berdasar perhitungan koefisien analisis jalur X1 terhadap Y dengan nilai 0,615 . Hasil perhitungan signifikansi analisis jalur didapatkan $t$-hitung 8,023 dan $t$-tabel 2,001 pada tingkat signifikansi 0,05 dengan derajat kebebasan 59. Karena $t$-hitung $>t$-tabel, disimpulkan bahwa koefisiensi jalur X1 terhadap $\mathrm{Y}$ adalah signifikan; (2) terdapat hubungan langsung antara budaya mikro kampus berdasar perhitungan nilai koefisien jalur X2 terhadap Y sebesar 0,363. Hasil perhitungan signifikansi koefisien analisis jalur didapatkan $t$-hitung 4,759 dan $t$-tabel 2,001 pada tingkat signifikansi 0,05 dengan derajat kebebasan 59 . 
Karena $t$-hitung $>t$-tabel, disimpulkan bahwa koefisiensi jalur X2 terhadap Y adalah signifikan; (3) terdapat hubungan langsung antara komitmen organisasi terhadap budaya mikro berdasar perhitungan nilai koefisien jalur X1 terhadap X2 sebesar 0,753. Hasil perhitungan signifikansi koefisien analisis jalur didapatkan $t$-hitung 8,852 dan $t$-tabel 2,000 pada tingkat signifikansi 0,05 dengan derajat kebebasan 60 . Karena $t$-hitung $>t$-tabel, disimpulkan bahwa koefisiensi jalur X1 terhadap X2 adalah signifikan. Dengan demikian, kepemimpinan dosen dapat ditingkatkan melalui komitmen organisasi dan budaya mikro kampus sehingga para dosen dapat terus meningkatkan kinerja mereka.

Kata kunci: Komitmen Organisasi, Budaya Mikro, dan Kepemimpinan

\section{A. Introduction}

Existence lecturer's is very important in achieving the educational goals as mentioned above. But the facts show that the role of lecturers is still very weak. One of the key in the effort to improve quality of education that now seemed so far behind, is a lecturer. It is clear that the quality and number of lecturers is crucial to the success of education. Empirically, there is still a phenomenon that is less supportive of the expected existence. Some phenomena still indicate the loss of exemplary lecturers as educators. ${ }^{1}$.

Phenomenon in the field found lecturer performance is less optimal because of low commitment. In the managerial order, the lecturer is in a very unfavorable position for the realization of his professional performance. Lecturers are more often treated as objects and subordinates, who are in position and conditioned by rigid bureaucratic management patterns, and in supervision that are sometimes contrary to the demands of professional and pedagogical performance. The lecturers are in a depressed, passive, reactive, and weakly powerless, self-impaired and non-authoritative state. Another phenomenon encountered, ie commitments agreed upon at the time of planning, was not implemented. This violation occurs either at the principal level, or at the lecturer level. Influence caused is a mismatch between planning and implementation, which resulted to

${ }^{1}$ Ahmad Amiruddin, Masalah Klasik Pendidikan Kita, dalam: Mengurai "Benang Kusut" Pendidikan Nasional (Jakarta. Indonesia: Badan Pertimbangan Pendidikan Nasional., 2013). 
the performance of lecturers to be down. ${ }^{2}$. The existence of a statistcentralized culture in the educational environment, consciously or unconsciously, has reinforced the concept of locus of control, due to too many "given" factors, such as centralized policies and inadequate operational support. According to ${ }^{3}$ the sense of organizational commitment, namely the loyalty of an individual to the organization. "The loyalty of an individual to the organization". In accordance with that opinion, ${ }^{4}$ states that organizational commitment is, " A sense of identification, loyalty, and involvement expressed by an employee to the organization or unit of the organization ". While ${ }^{5}$ organizational commitment reflects the extent to which an individual identifies with an organization and is committed to its goals". Individuals with a high organizational commitment would identify strongly with the organization and take pride in considering themselves a member". Organizational commitment is a state in which an employee identifies with particular organization and its goals, and wishes to maintain membership in the organization ${ }^{6}$.

A person's preoccupation with his job shows a high level of job involvement. A high level of commitment to the organization indicates a favor. ${ }^{7}$. The appropriateness, manifested in the form of workers' loyalty to the organization, and indicates the level of involvement in the organization. ${ }^{8}$. It is clear from the sense of organizational commitment. Organizational commitment is an employee's loyalty to

${ }^{2}$ M. Z. A. B. Himawan Bayu Patriadi, "Human Security in Local Wisdom Perspective: Pesantren and its Responsibility to Protect People," Procedia Environmental Sciences Journal Volume 28 (2015): 100-105.

${ }^{3}$ Jr. Schermerhorn, John R., Management. Eighth Edition. (New York: John Wiley \& Sons, Inc., 2005).

${ }^{4}$ Jr. Gibson, James L., John M. Ivancevich, James H. Donnelly, Organizations: Behavior, Structure, Processes. (Chicago: Richard D. Irwin., 1997).

${ }^{5}$ and Robert Kreitner Kinicki, Angelo, Organizational Behavior. Key Concepts, Skills \& Best Practices. International Edition (New York: McGraw-Hill \& Irwin., 2003).

${ }^{6}$ Stephen P. Robbins, Organizational Behavior. Eleventh Edition. International Edition (New Jersey: Prentice-Hall / Pearson., 2005).

7 Stephen P. Robbins dan Tomothy A. Judge, Organizational behavior (Jakarta. Indonesia: Salemba Empat Press, 2008).

${ }^{8}$ and R. R. Callister Wall, Jr., J. A., "Conflict and Its Management.," Journal of Management 21, no. 3 (2015): 517-23. 
the organization, as well as its level of involvement in the organization. "Loyalty to and heavy involvement in one's organization". ${ }^{9}$.

The existence of the lecturer as one of the subsystems in the open-system ${ }^{10}$. It appears that the three elements, namely loyalty, involvement and alignment are the substance of workers' commitment to the organization in which they work. According to ${ }^{11}$ organizational commitment represents an employee's orientation toward the organization in terms of his or her loyalty to, identification with, and involvement in the organization. Higher commitment can facilitate higher productivity. ${ }^{12}$. Committed workers have a feeling that their intentions and what they are doing, are not under pressure, but it is an investment for them. "Committed people have a sense of purpose and do not give up on pressure because they tend to invest themselves in the situation".13

For workers with strong commitment to the organization, generally will not terminate the employment to seek and obtain employment in other organizations. "Committed people are less likely to quit and accept other jobs". ${ }^{14}$. "Organizational commitment is the degree to which an employee identifies with the organization and is willing to put forth effort on its behalf". ${ }^{15}$. Employees with high organizational commitment will stretch themselves to help the organization through difficult times. Employees with low organizational commitment are likely to leave at the first opportunity for a better job. They have a strong itention to leave, so like employees with low job involvement, they are hard to

${ }^{9}$ Richard L. Daft, Management. Sixth Edition. Ohio: Thomson South-Western. [37] Fernald, L. Dodge, and Peter S. Fernald, (1999). Introduction to Psychology. Fifth Edition (Delhi: Publisher Distributors (regd)., 2003).

${ }_{10}$ and Cecil G. Miskel Hoy, Wayne K., Educational Administration; Theory, Research, Practice. Sixth Edition (New York: McGraw-Hill, Inc., 1991).

${ }^{11}$ Robbins, Organizational Behavior. Eleventh Edition. International Edition.

${ }^{12}$ Nur Khusniyah Indrawati, "Management by Inspiration: Implementation of Transformational Leadership on Business at Pondok Pesantren) Sunan Drajat," Procedia - Social and Behavioral Sciences Volume 115 (2014): 79-90.

${ }^{13}$ Kinicki, Angelo, Organizational Behavior. Key Concepts, Skills \& Best Practices. International Edition.

${ }^{14}$ Abdul Rahmat, “Clustering in Education” XX, no. 3 (2017): 311-24.

15 and Pattrick M. Wright Noe, Raymond A., John R. Hollenbeck, Berry Gerhard, Fundamental of Human Resources Management (New York: McGraw-Hill / Irwin, 2014). 
motivate. ${ }^{16}$. Which can mean higher job stress, higher insurance costs, and more lawsuits. All of these consequences of dissatisfaction, either directly or indirectly, are costly to organizations. ${ }^{17}$.

Another factor that affects lecturers' leadership is the microculture, which is the overall lifestyle of people of a particular social group, including all ideas, symbols, preferences, and material objects . According to ${ }^{18}$ culture as the complex mixture of assumptions, behaviors, stories, myths, metaphors, and other ideas that fit togeth . Culture is an overall lifestyle of people of a particular social group, including all ideas, symbols, preferences, and material objects. "Culture is the total lifestyle of people from a particular social grouping, including all the ideas, symbols, preferences, and material objects that they share" ${ }^{19}$.

According to ${ }^{20}$ special culture was contrary to the "parent" culture, then the symptoms are called counter-culture. Counter-culture does not always have to be given a negative meaning, because the symptoms can be used as an indication that the parent culture is considered less able to harmonize with the development needs. ${ }^{21}$ Analytically there can be a distinction between deviation and diversion, both of which are counter-culture. If any element of outer culture wants to be introduced into a society, it must first be prevented from qualifying the element as a fraud. Therefore, in introducing a relatively new cultural element, always to be highlighted the benefits

${ }^{16}$ Baowen Li, 'meng Zou, dan 'yufei Guo, "Business Process Analysis and Optimization on Road Traffic Law Enforcement of the Beijing Intelligent Traffic Management," Procedia - Social and Behavioral Sciences 138 (2014): 748-56, https:/ / doi. org/10.1016/j.sbspro.2014.07.252.

${ }^{17}$ G. Naor, M., Goldstein, S., M., Linderman, K., W. and Schroeder, R., “The role of culture as driver ofquality management and performance: infrastructure versus core quality practices," Decision Sciences 39 (2008): 671-702.

${ }^{18}$ Jr. Stoner, James A.F., R. Edward Freeman, and Daniel R. Gilbert, Management. Sixth Edition. International Edition (New Jersey: Prentice-Hall International, Inc., 2005).

${ }^{19}$ Stephen L. Franzoi, Social Psychology. Madison: Brown E Benchmark (Madison: Brown \& Benchmark Publishers., 1996).

${ }^{20}$ Soerjono Soekanto, Sosiologi, Suatu Pengantar. Edisi Baru Keempat (iJakarta: PT. RajaGrafindo Persada, 1997).

${ }^{21}$ and E. A. Mannix Jehn, K. A., "The Dynamic Nature of Conflict: A Longitudinal Study of Intragroup Conflict and Group Performance," Academy of Management Journal 2001 (2001): 238-251. 
or the real utility that turned out to be larger when compared with the old cultural elements. ${ }^{22}$.

Micro-culture is defined as a culture that prevails in certain organizational environments. Cultural elements that apply in the organization of the factory, not necessarily the same as the cultural elements prevailing in the school environment, government and so forth. Similarly, the cultural elements prevailing in the A school environment, may not necessarily apply as a whole in the school environment B. ${ }^{23}$

Culture at the organizational level, has 7 (seven) main characteristics, namely:

1. Innovation and risk taking. The degree to which employees are encouraged to be innovative and take risks.

2. Attention to detail. The degree to which employees are expected to exhibit precision, analysis, and attention to detail.

3. Outcome orientation. The degree to which management focuses on results or outcomes rather than on the techniques and processes used to achieve those outcomes.

4. People orientation. The degree to which management decisions take into consideration the effect of outcomes on people within the organization.

5. Team orientation. The degree to which work activities are organized around teams rather than individuals.

6. Aggressiveness. The degree to which people are aggressive and competitive rather than easygoing.

7. Stability. The degree to which organizational activities emphasize maintaining the status quo in contrast to growth. ${ }^{24}$

The culture of an organization also has impact on the commands shown by its members. Commitment is a condition in which members of a group give their effort, abilities, and loyalties to

${ }^{22}$ Mary Coulter, Management. Seventh Edition. International Edition (New Jersey: Prentice-Hall International, Inc., 2003).

${ }^{23}$ Neil Barnwell, Organization Theory, Concepts and Cases. Fourth Edition (New Jersey: Prentice-Hall / Pearson, 2002).

${ }^{24}$ Jehn, K. A., "The Dynamic Nature of Conflict: A Longitudinal Study of Intragroup Conflict and Group Performance." 
the organization and its pursuit of its goals in return for satisfaction. ${ }^{25}$. The micro-culture will influence the level of employee commitment to the organization. Commitment given to the organization, can be voluntary or compulsive. The existence of a person in the organization, not always based on a full commitment, because the commitment has a broad dimension. Commitments that are not given as a whole, voluntarily, can pose a sound ethical issue to employee performance. ${ }^{26}$.

Based on the notion of micro-culture can be synthesized that the micro-culture is related to the individual as a lecturer with the customs that exist in the surrounding environment. Habit here is highly dependent from various fields including the properties of each person in the surrounding environment. Habit here depends on many fields, including the properties of each person in the environment.

\section{B. Research Methodology}

This research was conducted from August to October 2017. The method used in this research is survey with path path analysis. According to ${ }^{27}$ structural $\mathrm{m}$ odel (path analysis) is used to analyze causal relationships between exogenous variables toward endogenous variables. In this research there are three variables that become object of research. two exogenous variables are organizational commitment $\left(X_{1}\right)$ and micro culture $\left(X_{2}\right)$ and one endogenous variable that is lecturer leadership $(\mathrm{Y})$. According $\mathrm{to}^{28}$ the exogenous variable is a variable that is assumed to occur because of causes outside the causal model or constellation, whereas the endogenous variable is a variable that results from exogenous variables.

Population is a region of gereralisasi consisting of objects/ subjects that have certain qualities and characteristics set by the

${ }^{25}$ and Lawrence Gales Hodge, B.J., William P. Anthony, Organization Theory: A Strategic Approach. Fifth Edition. International Edition (New Jersey: Prentice-Hall International, Inc., 1996).

${ }^{26}$ Daft, Management. Sixth Edition. Ohio: Thomson South-Western. [37] Fernald, L. Dodge, and Peter S. Fernald, (1999). Introduction to Psychology. Fifth Edition.

${ }^{27}$ Nurhayati Abbas, Bahan Ajar Statistik Penelitian (Gorontalo Indonesia: PPs Universitas Negeri Gorontalo Press, 2016).

${ }^{28}$ Sugiyono, Statistika Untuk Penelitian. (Bandung: Alfabeta., 1999). 
researchers to be studied and then drawn conclusions ${ }^{29}$. The sample is part of the number and characteristics possessed by the population ${ }^{30}$. The sampling technique uses simple random sampling. Assuming that lecturers' ability is truly homogeneous. The representative sampling in this research is 62 people from the total population of 124 people or by $50 \%$. Sampling in accordance with opinion ${ }^{31}$, "determination of sampling if less than 100 better taken all so that population research. If the number of subjects is large or more than 100 can be taken between $10-15 \%$ or $20-55 \%$.

This study uses sampling techniques based on the Harry King Nomogram described..$^{32}$ In this study, data collection techniques using tests, questionnaires and documents. The test is used to collect data on lecturers' leadership. Test is arranged in the form of multiple choice and refers to indicators of lecturer leadership. Questionnaires were used to collect data on the locus of control of micro culture. Questionnaires are designed in such a way as to record data about campus micro culture using a scale of 1-5. For organizational commitment as a factual variable, then a document is used. ${ }^{33}$. Data analysis techniques used are descriptive and inferential analysis. Descriptive analysis techniques used to obtain a description of the characteristics of the spread of the value of each score of variables studied. ${ }^{34}$. The data descriptions of the results were based on mean, median and group data modes. It also calculated the data variance. Distribution of data based on the frequency distribution table of data groups visualized in the form of histogram. ${ }^{35}$. Inferential analysis is used to test the research hypothesis. Because this research aims to

${ }^{29}$ Suharsimi Arikunto, Manajemen Penelitian (Jakarta: Rineka Cipta., 2000).

${ }^{30}$ Sugiyono, Business Research Methods (Quantitative Approach, Qualitative, and $R \in D$ D). Sixteenth print (Bandung: Alfabeta Press, 2012).

31 Neuman, Social Research Methods; Qualitative and Quantitative Approaches (Cambridge Mass: A Pearson Education Company, 2016).

32 and R. R. Callister Wall, Jr., J. A., "Conflict and Its Management. Journal of Management," Journal of Management 21 (1995): 517-523.

${ }_{33}$ and M. Toyama Gelfand, M. J., M. Higgins. L. H. Nishii, J. L. Raver, A. Dominguez, F. Mukakami, S. Yamaguchi, "Culture and Egocentric Perceptions in Conflict and Negotiation," Journal of Applied Psychology 2002 (2002): 833-845.

${ }^{34}$ S Hadi, Metodhology Research I (Jakarta. Indonesia: Andi Offset, 2017).

35 Dadhich and K. T. Bhal, "Bhal, Ethical Leader Behavior and LeaderMemberExchange as Predictors of Subordinate Behaviors," Journal for DecisionMakers 33 (2008): 4. 
get information about the influence between variables studied, the statistical test used is Path Analysis. ${ }^{36}$. This statistical test is used to test 3 (three) research hypotheses proposed by the researcher. The statistical hypothesis tested is:

The first hypothesis $\quad H_{0}: \beta_{y_{1}}=0$

$$
H_{1}: \beta_{y_{1}}>0
$$

The second hypothesis $H_{0}: \beta_{y_{2}}=0$

$$
H_{1}: \beta_{y_{2}}>0
$$

The third hypothesis

$$
\begin{aligned}
& H_{0}: \beta_{21}=0 \\
& H_{1}: \beta_{21}>0
\end{aligned}
$$

\section{Research Result and Discussion \\ 1. First Research Hypothesis}

The first research hypothesis is "There is a direct positive effect of organizational commitment to lecturer leadership ". This hypothesis is statistically formulated as follows.

$$
\begin{aligned}
& \mathrm{H}_{0}: \beta_{\mathrm{y} 1} 0= \\
& \mathrm{H}_{1}: \beta_{\mathrm{y} 1}>0
\end{aligned}
$$

Testing criteria:

Reject $\mathrm{H}_{0}$ if $\mathrm{t}_{\text {count }}>\mathrm{t}_{\text {table }}$ at the level of significance a selected with degrees of freedom $(\mathrm{db})=\mathrm{n}-\mathrm{k}-1$, in other circumstances accept $\mathrm{H}_{0}$.

From the calculation of coefficient value of path $X_{1}$ to $Y$ obtained value $0.615=\beta_{y 1}$. Based on the results of significance test calculation path coefficients obtained $t_{\text {count }}=8.023$ and $t_{\text {table }}=2.001$ at significance level $a=0.05$ with degrees of freedom $(d b)=59$. Because the value of $\mathrm{t}_{\text {count }}=8.023>\mathrm{t}_{\text {table }}=2.001$, we conclude that the coefficient of path $\mathrm{X}_{1}$ to $\mathrm{Y}$ is significant.

\footnotetext{
${ }^{36}$ Sugiyono, Statistika Untuk Penelitian.
} 


\section{Second Research Hypothesis}

The second research hypothesis is "There is a positive direct effect of micro culture on lecturer leadership". This hypothesis is statistically formulated as follows.

$$
\begin{aligned}
& \mathrm{H}_{0}: \beta_{\mathrm{y} 2} 0= \\
& \mathrm{H}_{1}: \beta_{\mathrm{y} 2}>0 \\
& \text { Testing criteria: }
\end{aligned}
$$

Reject $\mathrm{H}_{0}$ if $\mathrm{t}_{\text {count }}>\mathrm{t}_{\text {table }}$ at the level of significance a selected with degrees of freedom $(\mathrm{db})=\mathrm{n}-\mathrm{k}-1$, in other circumstances accept $\mathrm{H}_{0}$.

From the calculation of coefficient value of path $X_{2}$ to $Y$ obtained value $0.363=\beta_{y 2}$. Based on the calculation results obtained path coefficient significance test $t_{\text {count }}=4.759$ and $t_{\text {table }}=2.001$ at significance level $a=0.05$ with degrees of freedom $(d b)=59$. Because the value of $\mathrm{t}_{\text {count }}=4.759>\mathrm{t}_{\text {table }}=2.001$, we conclude that the coefficient of path $\mathrm{X}_{2}$ to $\mathrm{Y}$ is significant.

\section{Third Research Hypothesis}

The third research hypothesis is "There is a positive direct effect of organizational commitment to micro culture". This hypothesis is statistically formulated as follows.

$$
\begin{aligned}
& \mathrm{H}_{0}: \beta_{21} 0= \\
& \mathrm{H}_{1}: \beta_{21}>0 \\
& \text { Testing criteria: }
\end{aligned}
$$

Reject $\mathrm{H}_{0}$ if $\mathrm{t}_{\text {count }}>\mathrm{t}_{\text {table }}$ at the level of significance a selected with degrees of freedom $(d b)=n-k 1$, in other circumstances accept $H_{0}$.

From the calculation of coefficient value of path $X_{1}$ to $X_{2}$ obtained value $0.753=\beta_{21}$. Based on the results of test calculations signifiknsi path coefficients obtained $\mathrm{t}_{\text {table }}$ value $=8.852$ and $\mathrm{t}_{\text {table }}=$ 2.000 at significance level $a=0.05$ with degrees of freedom $(\mathrm{db})=60$. Because the value of $t_{\text {count }}=8.852>t_{\text {table }}=2.000$, we conclude that the coefficient of path $X_{1}$ to $X_{2}$ is significant.

The test results of the three hypotheses can be visualized in the constellation images of inter-variable effects as in Figure 5. 


\section{Conclusion}

From the findings and discussion of research results it can be concluded some of the following: There is a positive direct effect of organizational commitment to the lecturer's leadership, meaning the absence of commitment can reduce organizational effectiveness. Lecturer with a high organizational commitment would be strongly with the organization and take pride in consider themselves a member. Organizational commitment represents an lecture's orientation toward the organization in terms of his or her loyalty to, identification with, and involvement in the organization. There is a positive direct effect of micro culture towards the lecturer's leadership, meaning that the culture creates conditions in the organization whereby members are willing to commit themselves to the pursuit of the organization's goals in exchange for some general state of satisfaction. A strong culture can enhance the likelihood that members will display a high degree of commitment. Over time, the individual feels a sense of identity with the group and is even willing to make sacrifices for it. This, in turn, leads to a deeper sense of commitment. Thus, one of the prime requirements for, or conditions of commitment is the sense of identification with the organization that culture provides

There is a direct positive influence of the lecturers' organization's commitment to micro culture, meaning that the culture of an organization also has impact on the degree of commitment shown by its members. Commitment is a condition in which members of a group give their effort, abilities, and loyalties to the organization and its pursuit of its goals in return for satisfaction. This issue of involuntary commitment, in which an individual is placed in a mental institution against his or her will, raises another ethical question. It is a practical matter, concerning freedom in everyday life, not a matter of research or licensure.

Based on the research findings, the conclusions and implications of the research can be put forward some suggestions as follows. To the lecturers, build an organizational commitment, if the lecturer does not have a strong commitment to his institution is not possible to perform positively. ecturers need to play a role in creating micro-culture in their work environment. Micro-culture is 
more influenced by the human resources in it, because the microculture is a culture that is in the scope of work. Thus, the greater the human resource intention to improve micro-culture, the better results will be achieved. To other researchers it is advisable to re-validate the instrument used if you want to use this research instrument and enrich the variables related to the leadership of the lecturer[.]

\section{REFERENCES}

Abbas, Nurhayati. Bahan Ajar Statistik Penelitian. Gorontalo Indonesia: PPs Universitas Negeri Gorontalo Press, 2016.

Amiruddin, Ahmad. Masalah Klasik Pendidikan Kita, dalam: Mengurai "Benang Kusut" Pendidikan Nasional. Jakarta. Indonesia: Badan Pertimbangan Pendidikan Nasional., 2013.

Arikunto, Suharsimi. Manajemen Penelitian. Jakarta: Rineka Cipta., 2000.

Coulter, Mary. Management. Seventh Edition. International Edition. New Jersey: Prentice-Hall International, Inc., 2003.

Dadhich and K. T. Bhal. "Bhal, Ethical Leader Behavior and LeaderMember Exchange as Predictors of Subordinate Behaviors." Journal for Decision Makers 33 (2008): 4.

Daft, Richard L. Management. Sixth Edition. Ohio: Thomson SouthWestern. [37] Fernald, L. Dodge, and Peter S. Fernald, (1999). Introduction to Psychology. Fifth Edition. Delhi: Publisher Distributors (regd)., 2003.

Franzoi, Stephen L. Social Psychology. Madison: Brown E Benchmark. Madison: Brown \& Benchmark Publishers., 1996.

Gelfand, M. J., M. Higgins. L. H. Nishii, J. L. Raver, A. Dominguez, F. Mukakami, S. Yamaguchi, and M. Toyama. "Culture and Egocentric Perceptions in Conflict and Negotiation." Journal of Applied Psychology 2002 (2002): 833-845.

Gibson, James L., John M. Ivancevich, James H. Donnelly, Jr. Organizations: Behavior, Structure, Processes. Chicago: Richard D. Irwin., 1997.

Hadi, S. Metodhology Research I. Jakarta. Indonesia: Andi Offset, 2017. 
Himawan Bayu Patriadi, M. Z. A. B. "Human Security in Local Wisdom Perspective: Pesantren and its Responsibility to Protect People." Procedia Environmental Sciences Journal Volume 28 (2015): 100- 105.

Hodge, B.J., William P. Anthony, and Lawrence Gales. Organization Theory: A Strategic Approach. Fifth Edition. International Edition. New Jersey: Prentice-Hall International, Inc., 1996.

Hoy, Wayne K., and Cecil G. Miskel. Educational Administration; Theory, Research, Practice. Sixth Edition. New York: McGrawHill, Inc., 1991.

Jehn, K. A., and E. A. Mannix. "The Dynamic Nature of Conflict: A Longitudinal Study of Intragroup Conflict and Group Performance." Academy of Management Journal 2001 (2001): 238- 251.

Judge, Stephen P. Robbins dan Tomothy A. Organizational behavior. Jakarta. Indonesia: Salemba Empat Press, 2008.

Kinicki, Angelo, and Robert Kreitner. Organizational Behavior. Key Concepts, Skills \& Best Practices. International Edition. New York: McGraw-Hill \& Irwin., 2003.

Li, Baowen, 'meng Zou, dan 'yufei Guo. “Business Process Analysis and Optimization on Road Traffic Law Enforcement of the Beijing Intelligent Traffic Management." Procedia - Social and Behavioral Sciences 138 (2014): 748-56. https://doi. org/10.1016/j.sbspro.2014.07.252.

Naor, M., Goldstein, S., M., Linderman, K., W. and Schroeder, R., G. "The role of culture as driver ofquality management and performance: infrastructure versus core quality practices." Decision Sciences 39 (2008): 671-702.

Neil Barnwell. Organization Theory, Concepts and Cases. Fourth Edition. New Jersey: Prentice-Hall / Pearson, 2002.

Neuman. Social Research Methods; Qualitative and Quantitative Approaches. Cambridge Mass: A Pearson Education Company, 2016.

Noe, Raymond A., John R. Hollenbeck, Berry Gerhard, and Pattrick M. Wright. Fundamental of Human Resources Management. New York: Mc Graw-Hill / Irwin, 2014. 
Nur Khusniyah Indrawati. "Management by Inspiration: Implementation of Transformational Leadership on Business at Pondok Pesantren) Sunan Drajat." Procedia - Social and Behavioral Sciences Volume 115 (2014): 79-90.

Rahmat, Abdul. "Clustering in Education" XX, no. 3 (2017): 311-24.

Robbins, Stephen P. Organizational Behavior. Eleventh Edition. International Edition. New Jersey: Prentice-Hall / Pearson., 2005.

Schermerhorn, John R., Jr. Management. Eighth Edition. New York: John Wiley \& Sons, Inc., 2005.

Soekanto, Soerjono. Sosiologi, Suatu Pengantar. Edisi Baru Keempat. iJakarta: PT. RajaGrafindo Persada, 1997.

Stoner, James A.F., R. Edward Freeman, and Daniel R. Gilbert, Jr. Management. Sixth Edition. International Edition. New Jersey: Prentice-Hall International, Inc., 2005.

Sugiyono. Business Research Methods (Quantitative Approach, Qualitative, and $R \in \mathcal{E} D)$. Sixteenth print. Bandung: Alfabeta Press, 2012.

- - - . Statistika Untuk Penelitian. Bandung: Alfabeta., 1999.

Wall, Jr., J. A., and R. R. Callister. "Conflict and Its Management." Journal of Management 21, no. 3 (2015): 517-23.

- - . "Conflict and Its Management. Journal of Management." Journal of Management 21 (1995): 517-523. 
